\title{
SEEKING THE CIVILIZATIONAL GHOSTS: SOME REMARKS ON CHINESE AND RUSSIAN APPROACHES TO INTERNATIONAL LAW THROUGH CIVILIZATIONAL VALUES
}

\author{
Battagodage Punsara Aravinda Amarasinghe* \\ Institute of Law and Politics, Scuola Superiore Sant Anna, Pisa, Italy, E-mail: \\ punsaraprint10@gmail.com
}

(Received: December 2019; Accepted: March 2020; Published: June 2020)

\begin{abstract}
This article seeks to examine the rigor of civilizational values in modern international law as a crucial factor and how historically different civilizational values have inculcated different approaches to international law. While critiquing the civilizational rhetoric built by European nations in creating Eurocentric international law, this article brings how international law has been perceived by China and Russia following their historical complexities. Results emerge from this paper will demonstrate the different diversity in international law.
\end{abstract}

Keywords: Civilization, Colonialism, Pragmatism, China, Russia, Identity.

\section{Introduction}

The key question of civilization in the realm of international law is vague and a complicated question that gives no exact clue. Yet, the phrase "civilization" has been a crucial term that has upheld its relevance in parallel to the historical development of international law. In tracing the most outrageous and dubious history of international law filled with biased narratives and many other inexplicable anomalies, one can easily comprehend the decisive role played by the phase "civilization" in constructing some of the ironies of international law. The interplay between the importance of civilization and the construction of international law has been mainly imbued with the idea of glorifying one civilization or culture and vanquishing the other. This formula stands as an irrefutable logic since the days of yore of world civilizations. When Greeks excelled themselves after defeating Persians and even prior to that, their attitude towards non-Greeks were taken a pessimistic, crude and darker one as their understanding of civilization was confined

\footnotetext{
* Corresponding author: Battagodage Punsara Aravinda Amarasinghe. E-mail: punsaraprint10@gmail.com
}

Copyright () 2020 The Author(s). Published by VGWU Press

This is an Open Access article distributed under the terms of the Creative Commons BY 4.0 license (Creative Commons - Attribution 4.0 International - CC BY 4.0) which permits unrestricted use, distribution, and reproduction in any medium, provided the original author and source are credited. 
Amarasinghe, B.P.A, (2020)

Seeking the civilizational ghosts: Some remarks on Chinese and Russian approaches to international law through civilizational values

to Greece. Hence, citizens from the outside world became barbarians. When Rome began its growth from being a tiny city near river Tiber to become a world conqueror after their victory over Carthage in Punic wars, their attitude towards the other nations in diplomacy was predominantly based on their feeling of superiority which eventually culminated in their victory over King Antiochus IV in 164BC resulting Rome's unparalleled hegemony over both Western and Eastern nations. Since then till Rome reached its ebb, the mechanism of international diplomacy between Rome and all other nations was based on Rome's superiority over the other. As a matter of fact, these historical elucidations make our understanding much easier about analyzing the gravity of civilization in international law since its very primary stage and it indicates how fascination towards civilizational values filled with the sense of superiority over other leading to outnumber other nations.

In appreciating and critically evaluating the historiography of modern international law, it becomes an evident factor that the values standing in modern-day international law are the creations of European Christian civilization. Francisco Vittoria, Alberico Gentili and Hugo Grotius are usually regarded by students of international law as the holy trinity of constructing modern European narrative of international law and it is a fact beyond dispute that all three had emerged within the Christian civilization of post-medieval Europe despite their ideological differences. From these three great stalwarts of the development of international law, Spanish Jesuit jurist Vitoria remained a champion of preserving natural rights as his opinion on native Indian tribes under Spanish expansion was driven by apotheosizing the idea of natural law as the very foundation of the international legal order [1]. He was known for his partial view on native Indian tribes in America as he regarded them to be a nation in their own system of governance. Prior to this revolutionary exclamation of Vitoria, it was asserted that the human affairs were governed by divine law and papal authority was held in high esteem and Christian monarchs in Europe sought papal authority to legitimize their territorial invasions beyond Christendom as a justified spread of Christianity over heathens. The religious decree played real importance of validating the acts of the sovereign. As an example, Pope Alexander VI's papal bull divided the known world between Portuguese and Spanish empires. However, Vitoria liberated the application of international law from extreme religious dogma, yet, his reluctance to admit native Indians as equal states of Christian Europe clearly denoted his civilizational standards.

The pervading picture of the historiography in international law is not other than a civilizational clash and a complex discourse emerged from the superior civilizations that would legitimize their claims under some legal guise. Especially in the western world order that flourished after the Peace of Westphalia, European picture of the law of nations depended on the reception of traditional Christian values and their

2 Journal of Legal Studies Volume 25 Issue 39/2020 $\checkmark$ sciendo ISSN 2457-9017; Online ISSN 2392-7054 
common civilizational values stood as a set of constitutive norms that governed the relationship among the family of nations which was sometimes depicted as "ius publicum Europaeum" and it excluded non-Christian, non-European nations from their domain of the law of nations.

The world order existing today has demonstrated the emergence of new players above the traditional Euro American hegemony in world dominance. Especially, unmitigated economic growth in China has intensified its political strength that has created uncertainty in the Anglo-American world about the persistence of their dominance in the future. On the other hand, the rise of Russia under president Putin and it's steeping desire to restore its previous position as a key player in international political affairs is another notable factor to concern. It is not a mere conjuncture that these new political growths will significantly change international legal order from its traditional Eurocentric perspective. Also, it is important to understand the civilizational roots stemming from Chinese and Russian approaches to international law will undoubtedly play a more crucial role in their interaction with Eurocentric international law. In this article, I attempt to trace the civilizational roots that had culled the understanding and reception of international law in China and Russia. Especially this paper will suggest that the different approaches to international law from China and Russia throughout their historical encounters with the West and my contention in this paper will prove that the idea of Eurocentric construction of international law is no different from what both China and Russia perceived as an international legal system from their civilizational perspectives. The purpose of this paper is to examine the gravity of the intrinsic civilizational values of China and Russia in creating their international legal norms and the study of these roots will unveil both countries yearning to aggrandize their position in international legal order. Tracing civilizational values behind the pillars of international law would be rather audacious or perhaps an ambiguous task and consequently, scholars cannot exactly claim how many civilizations are there nowadays. Yet, understanding the civilizational perspective from these two unique states will help us to understand their world view better. Because one cannot neglect what David Kennedy wrote about the general nature of international law as he stated it is fundamentally being practiced differently in different places [2].

\section{Philosophical speculation behind the Chinese attitude towards an international legal order}

Examining the philosophical tradition existed in ancient China becomes an indispensable factor before asserting how China looked into international law because every aspect in the Chinese public domain has aligned parallel to its great philosophical tradition dating back to several thousand years. $L i$ and $F a$ were the two 
Amarasinghe, B.P.A, (2020)

Seeking the civilizational ghosts: Some remarks on Chinese and Russian approaches to international law through civilizational values

great philosophical traditions existed in China in its antiquity and those two concepts have continued to spread its greater importance throughout every aspect in Chinese society. $L i$ has been often referred to the moral rules in character in accordance with natural law. The concept of $\mathrm{Li}$ in ancient Confucian ideology set the yardstick for the relationship between master and servant, host and guest. It's scope fundamentally focused on proper social cultivation. The general nature of $\mathrm{Li}$ could be perhaps compared with what western jurisprudence propounded as natural law as $L i$ 's objectivity was much akin to the later, whereas the concept of $F a$ mainly stands as a strict formalist interpretation. One can mistakenly fathom $F a$ as the Chinese resemblance of positive law, but, it is important to understand the Chinse attitude to legalism was totally different from how it was perceived and practiced in the West. In Chinese understanding of the law was inherently based on punishing the wrongdoers and there was no feeling prevalent among citizens that law would eventually protect the civil interests. The only reality Chinese were aware was that if they violate the imperial law, they would be punished and the law's instrument such as court and written codes were considered to be tools that would deter the people. One Chinese proverb described the law as "Law is meant for a base person but not for a gentleman" [3]. In ancient Chinese culture, the attitude towards Li took a much-honored position as it was believed to be more effective and helpful in continuing the harmonious structure in society. Concerning the prominence played by $L i$ in Chinese notion of international legal order Pan Junwu states:

"According to Li, the hierarchical structure in a civil society is built on five natural relationships: father and son; ruler and subject; husband and wife; elder and younger brother; and the relationship between friends. According to this theory, the subject should obey the ruler; the younger should obey the elder; the female should obey the male; the lower part should obey the higher part. Before China was forced by Western powers to open its doors in the I84os,5 the Chinese concept of an "international Li" (or international law) held China as the center of the world. The basic assumption was that the international order should be based on China's cultural superiority. Therefore, the relations between China and its neighbors were thought to be similar to the ones between father and son, husband and wife, and king and subject, which contained anything but the concept of sovereign equality and independence. The tribute system which China set up for its neighboring countries typically expressed this hierarchical concept of relationships. Thus, when modern international law based on the sovereign equality and independence of all states was introduced to China, China was completely astonished.' In short, the international Li held by the Chinese was a hierarchical and anti-egalitarian Sino-centric world order that rested on moral virtue rather than military power" [4].

\footnotetext{
4 Journal of Legal Studies Volume 25 Issue 39/2020 $\checkmark$ sciendo ISSN 2457-9017; Online ISSN 2392-7054 Web: publicatii.uvvg.ro/index.php/jls. Pages $1-30$
} 
Understanding the way China treats international law becomes much conspicuous after examining its philosophical roots imbedded with its ancient civilization. As Junwu stated concept of $L i$ pictured China's supreme position in international affairs as the center of the earth. China kept her position aloof since antiquity as an isolated civilization without getting many external influences as other civilizations encountered. Indeed, it was not much affected by Greco Roman cultures even to the extent of how Greek culture influenced the ancient Indian civilization. The cultural superiority displaying China as the very core of the earth was one of the predominant features Chinese were preserving until they envisaged Western invasions in the 19th century.

The hierarchical relations with its neighboring countries always tended to portray China as a paternal sovereign who would treat neighboring states like a father treating his children. The traditional Chinese view named China as "T'ien Hsia" and the emperor of China was known as the eye of heaven. Such a galactic status upon an emperor affirmed him to a person with cosmic nature above everything. Also, Chinese characters indicating name China today remain Chung Kио "The Middle Kingdom" which further connotes how China still yields to be the central figure in world civilizational order [5]. In fact, China never perceived herself as one of the nations among many, but the world order itself. The ancient Roman concept of Jus Gentium elaborating the method of conducting legal affairs among states or natural legal principles did not exist in the Chinese approach to their relations with other states. The Chinese attitude towards international law could be aptly understood by examining the historical details of the first British state delegation to imperial China in 1793. This delegation was headed by Lord McCartney under the patronage of King George III of Britain and his duty was to initiate a trade affair with China. His memories have mentioned the veneration expected by Chinse emperor from the foreign delegation and it had clearly elucidated the choice of gifts chosen by British delegation in order to convince the Chinese emperor that he is not the only sovereign in the world. For instance, Lord McCartney stated that he deliberately chose a modern world map showing China is not the real middle kingdom in the world and the other gifts included a model ship as a sign of showing there are other maritime powers besides Chinese.

\section{Confucian model in Chinese International Relations}

Confucian philosophy and his teachings took a leading role in every aspect of the Chinse society as a great moral force. Nevertheless, painting Confucian philosophy as a pacifist teaching has been a major myth nowadays. On the contrary, Chinese history has vividly illuminated the rigor of imperial foreign policy that grew under the Confucian influence in China. The imperial expansion of China and its central 
Amarasinghe, B.P.A, (2020)

Seeking the civilizational ghosts: Some remarks on Chinese and Russian approaches to international law through civilizational values

foreign policy towards its neighbors were inherently based on placing China as the superior state. If the expansion of china was simply driven by mere cultural assimilation, it would have been an illusionary vision to explain how Chinese power since Quin dynasty (221-206 BC) began to grow till the time of Quing empire (16441911). The historical statistics on Chinese involvements in interstate warfare are the best evidence that simply disrupts the myth of idealizing Confucian pacifism as the cardinal feature in Chinese diplomacy because the historical references have shown China involved in 3131 wars from Quin dynasty to last Quing dynasty that proved China had been violent in the same intensity as how Europe violent was with their interstate wars [6]. Victor Hui has stated, "War, not Confucian ideals, explains how China expanded from the Yellow River valley in the Warring States era to the continental empire in the Quing dynasty" [7].

Moreover, Chinese emperors were well aware of the repercussions of being more pacifist in their diplomacy as they considered it an act of timidity. As an example during Han dynasty in the period of Emperor Xuan, his son (future Emperor Yuan) was keen on appointing many Confucian pacifists in key positions of the imperial court which finally exasperated the emperor himself, who regarded it as a manner of weakening the statecraft. This simple story reveals the flare held by Chinese rulers in preserving their hegemony rather than idealizing pacifism.

The Chinese conception of considering themselves superior was always an inherent part of interstate relations, which later transformed into their vision of international law. In examining the Chinese maritime expansion in Ming dynasty, the salient principle carried out by Ming mariners was to explore distant seas and it was further strengthened by creating commercial avenues for China. However, during one of the treasure voyages of Ming dynasty, it's famous admiral Zheng He and his fleet were attacked by the hostile Sinhalese ruler in Kotte kingdom of Sri Lanka around 1410 whish caused to return of Zheng with a large Chinese troop and it easily defeated Sinhalese army, which resulted in taking Kotte ruler and other Sinhalese officials as captives to China [8]. The historical reports have narrated the waging war against Kotte was mainly agitated by the disrespectful and hostile behavior of Sinhalese towards Chinese fleet. Even after presenting Kotte ruler as a Chinese prisoner, Chinese emperor granted him pardon after receiving the meek apology and complete obedience. This is just an example that we can trace the Chinese perception of small nations. As China located herself as the middle kingdom or omnipotent cultural, political authority, Chinese attitude towards less powerful states always took a paternal bent as it was duly portrayed in the concept of $L e$.

Gift giving has been another intrinsic feature in Chinese mode of international legal and state practices, which dates back to the original teachings of China's ethical guru Confucius, whose notion of uplifting a state was not essentially attributed law and it

6 Journal of Legal Studies Volume 25 Issue 39/2020

$\$$ sciendo ISSN 2457-9017; Online ISSN 2392-7054.

Web: publicatiii.uvvg.ro/index.php/jls. Pages $1-30$ 
was rather based on virtue. According to Confucius "Law is necessary when virtue fails. In contrast, if a ruler leads first with law, the populace will not have a conscience and will only fear punishment" [9]. In emulating the principle of virtue, the importance given to ritual has played a rather significant one, because, in the Chinese ancient book of rites, the governance and giving were linked to ritual. It was believed that gift-giving as a ritual was filled with reverence and a sense of generosity and also it was expected to receive blessings from the receiver. This idea of gift-giving continues even today as an important principle in the Chinese approach to interstate relations. In the Chinese world view, China being the central state of the earth continues its influence towards smaller states in a poignant way through giftgiving. As a matter of fact, this Confucian ideal has aptly worked in most of the states where China upholds its influence. Particularly, in Sri Lanka, the pro Chinese governments of Sirimavo Bandaranaike and Mahinda Rajapaksa were frequently blessed with Chinese gifts grants as the country's only international convention center and theater were builds by the Chinese government as tokens of comity [10]. It clearly indicates how fervently the Chinese Confucian ideal of gift-giving works in the modern Chinese view on interstate relations, which always has been an inexplicable dilemma to the Western world to understand.

\section{Understanding Sinocenric mode of sovereignty}

Before the culmination of China's encounters with Western nations in the Opium War (1839-1842), which brought China to its knees in a humiliating manner before British, China was the sole sovereign and this was evident when China denied the entry to European nations for free trade beyond the city of Canton and Chinse did not understand the idea of sovereign equality and kept insisting Western diplomats to perform various rituals before the Quing emperor. However, the conclusion of Opium war followed by the Treaty of Nanjing (1842) which clearly marked the integration of China into Anglo-American understating of the international legal order. Yet, the pathetic blow stuck upon the Chinese nation by subordinating themselves to Western powers still echoes among Chinese even in the writings of modern Chinese international legal scholars. As an example in describing Chinese philosophical pillars behind its understanding of international law, Professor Pan Junwu states:

"But since the 1840s, as the defeated party in a series of wars with the West, it was China that was treated as the "uncivilized state" by the Western powers and it gradually declined into a semi-colonized position. It was during this period that Western powers destroyed the then concept of China's international Li" [11].

The above-mentioned extract from Prof. Junwu emphasizes the impoverished status of China envisaged as a morally and materially degenerated nation after its defeat before Western nations. In fact, the way China considered herself as the middle 
Amarasinghe, B.P.A, (2020)

Seeking the civilizational ghosts: Some remarks on Chinese and Russian approaches to international law through civilizational values

kingdom reached its ebb as the West began to treat China in the same way as to how they treated colonized Asian and African nations.

The political cataclysm and steady decline of China in the $19^{\text {th }}$ century influenced Chinese from another important perspective because it was the century that brought the western idea of international law into Chinese minds. According to historical sources, the maiden contact between China and western conceptualized international legal order dates back to 1689 when the Treaty of Nerchinsk was signed between the Russian empire and imperial China as the very first one from the serious of treaties. The treaty was equal and formed under contemporary international law norms, especially the treaty process was headed by a Jesuit missionary called Thomas Pereira whose activities were known to be much influential in the court of Knaxi emperor [12]. The daily diary maintained by Pereira indicates that he lectured on some accepted principles in European international law to the Chinese emperor. It was by no means a comprehensive analysis as Pereira was not a legal scholar, yet this event can be taken as China's first exposure to the gaze of international law. Afterward, it took another two centuries to intensify the development of international law in imperial China and this time its infiltration came through the pressured circumstances China faced in the dawn of the opium war. The $19^{\text {th }}$-century turmoil that swallowed Chinese static world view of considering themselves the superior core of world civilization finally compelled China to reconsider their position and from one side it was further bolstered by the newly emerged Chinese young intellectuals studied abroad as they perceived the grave necessity of implementing some progressive reforms in China in order to wake from its aged long slumber. The first attempt at incorporating European international legal standards was manifested in the early $19^{\text {th }}$ century when the spread of opium appeared to be a serious issue in China. Lin Zexu, who happened to be the commissioner in Canton wrote a letter to Queen Victoria in 1839 and his message has more or less consisted of international legal theoretical knowledge he indoctrinated from reading some extracts from Emerich de Vattel's "Le droit des genes". The usage of Vattel's book by a minister in imperial China did not emerge out of the blue as this idea was supported by American diplomat Parker who translated the text into Chinse which provided muchelucidating references to support Lin's letter to Queen Victoria. The letter written by Lin has firstly invoked his arguments by stating two universally acknowledged principles such as emperor would publicize whatever is beneficial for the world (tianxia) and he would eliminate whatever is harmful (tianxia). In the content of the letter Ling has displayed the Confucian understanding of the world and further elaborated on how the spread of Opium becomes a problem in Chinese society. He states "opium trade 'rouses indignation in every human heart, and is utterly inexcusable in the eyes of celestial reason' [13]. Having cited some excerpts from

8 Journal of Legal Studies Volume 25 Issue 39/2020

$\checkmark$ sciendo ISSN 2457-9017; Online ISSN 2392-7054.

Web: publicatiii.uvvg.ro/index.php/jls. Pages $1-30$ 
Vattel's work, Ling paid astute attention to the importance of applying Chinese laws to foreigners in China. Quing dynasty in China had ordered the death penalty whoever involved in opium smuggling by decapitation. However, in his letter to Queen Victoria Ling had attempted to point out that it would be possible to release British prisoners as they had shown remorse. This was primarily driven by how the British treated the Chinese legal system and the state as a barbarous and semi civilized one. Especially in examining the paramount factors pushed British to wage Opium war against Chinese, "Freeing British merchants from the abominable fate awaited at the hands of Chinese officials" was one of the main motives put forward by British in Opium war. The civilizational supremacy Chinese held in high esteem was not what Western nations perceived from Chinese legal system and this ideological difference paved the way to British contempt of Chinese legal order as semi barbaric whereas Chinese could not find any reason behind calling them uncivilized as their main take on the law was formed by $L i$ which bestowed paternal duty upon the emperor, also $L i$ necessarily urged disputants to resolve their conflicts through a dialog rather than taking any judicial process. Apart from the central doctrine of Li Chin's attitude to European international law remained below the periphery except for the above mentioned situations such as Jesuit priest Pereira's involvement in forming the treaty of Nerchinsk between Russian empire and imperial China in 1689 and Lin's letter to British Queen which supported by some ideas Lin acquired from Vattel's work.

When China was grappling with newly emerged Western influences that were looming before the Chinese territory their understanding of European international law was edified by the missionaries resided in imperial China as they exposed the elements of Europeanized international legal principles to China. As I mentioned above, China's maiden association with Jus Gentium was attributed to Thomas Pereira in 1689 and the next major turn took place in 1864 when an American missionary and a Sinologist called William A.P Martin translated Henry Wheaton's "Elements of International Law" into Chinese that finally granted a coherent outline of European notion of international law to China although such an endeavor was carried out twenty years later since China suffered humiliation from western nations in Opium wars. Martin's attempt to international law to China who was in a semi colonized nation at that time was important yet, it is important to understand that Europe was reluctant to apply its standard international law to any non-European state. As international law was conceived out of Western civilization as a mode to resolve the disputes among European states and conduct interstate affairs, it's applicability upon non-European, non-Christianized nations always were driven by a sense of skepticism and civilizational contempt Europeans maintained towards non-Western nations. It was such an irony that as in the same manner how China 
Amarasinghe, B.P.A, (2020)

Seeking the civilizational ghosts: Some remarks on Chinese and Russian approaches to international law through civilizational values

considered herself as the middle kingdom or the most superior civilization on earth, Western nations considered the hallowedness of international law as their sole creation. The $19^{\text {th }}$-century international law scholar William Hall states:

"Scarcely necessary to point out that as international law is a product of the special civilization of modern Europe, and forms a highly artificial system of which the principles cannot be supposed to be understood or recognized by countries differently civilized, such states can only be presumed to be subject to it as inheritors of that civilization. They have lived, and are living under the law, and a positive act of withdrawal would be required to free them from it's restrains. But states outside European civilization must formally enter into the circle of law-governed countries" [14].

In particular, theorizing international law after the Treaty of Westphalia in 1648 was mainly focused on uplifting sovereign power and balancing foreign relations. The need of maintaining harmony in the European geopolitical map was epitomized by the regulations adopted at Westphalia, but with growing colonial desires of European nations and its imperial expansion in African and Asian territories, their understating of international law reached a different direction. The intellectual contributions made by European scholars in establishing Eurocentric positivistic international law in the $19^{\text {th }}$ century had shown how international law is born out of the Roman notion of Jus Gentium based on natural reason. As David Kennedy aptly described in his article titled "International Law and $19^{\text {th }}$ Century History of an Illusion", the events occurred in the aftermath of Westphalian peace led many theorists to locate natural law as a binding force outside sovereignty, however, the $19^{\text {th }}$-century power politics may have twisted the arms of international legal scholars to accept the final binding force international norms cannot be understood beyond the absolute nature of sovereignty [15]. Yet, the sovereignty that existed beyond European boundaries was not captured by the gaze of $19^{\text {th }}$ century newly emerged international legal scholars when they theorized the new development of international law. Many of the $19^{\text {th }}$ century scholars believed the sole applicability of international law should only be confined to European Christian states. In the late $18^{\text {th }}$-century, Robert Ward argued the fact that different sets of rules would be applied upon different nations as to how cultural and religious diversities in world civilizations had changed the moral order and reason. Wards had insisted on the shared cultural system dating back to GreekRoman antiquity and the belief in Christianity enable European states to rely on international law as a common system [16]. Cobold Toze was another $19^{\text {th }}$-century thinker who advocated for the European supremacy of the $19^{\text {th }}$-century international law. He argued, "The existence of a European law of nations is undoubted and distinguishable from Barbarian people because of the many usages and customs of the nations of Europe observe among them, both in times of war and peace" [17].

10 Journal of Legal Studies Volume 25 Issue 39/2020

$\checkmark$ sciendo ISSN 2457-9017; Online ISSN 2392-7054.

Web: publicatii.uvvg.ro/index.php/jls. Pages $1-30$ 

civilizational values

Indeed, this was the scholarly picture depicted on Non-European nations and why they should not be welcomed to the family of the law of European nations when China struggled to understand the enigma of international law in the post Opium war context. When Martin translated the "Wheaton's Elements of International Law" into Chinese in 1864, his attempt of introducing international law into Chinese people was scorned by several Western delegates resided in China. Mainly it was reported that French diplomat was vehemently opposing Martin's attempt of introducing western international law to Chinese people as he foresaw it as a threat to European privileges in China.

The project carried out by a Missionary like Martin should be examined from a much a wider point of view and his position on Chinese culture and its civilizational values were primarily not on par with what he was about to introduce to China. Nevertheless, his determination was intrinsic regarding amalgamating European international law with China despite its salient civilizational difference. However, the real dilemma arose from Martin's translation of Wheaton's International Law was that being a Christian missionary he emphasized the idea of universality in international law from his approach. In fact, many of Jesuit missionaries who devoted themselves to spreading Christianity in China developed a keen interest in comparing ancient Confucian doctrines with Christianity and affirmed Confucian philosophy was much akin to what Christ conveyed in New Testament. These circumstances played a greater role in shaping the process of introducing international law based on universal morality that went on to inculcate the discipline of international legal order in imperial china, but ironically the so-called universal justice or moral order Martin intended to convey Chinese were withering away from the contemporary international law of $19^{\text {th }}$ century as a result of Europe's predilection on the imperial expansion that was only supported by their positivistic stances in international law. However, regardless of this paradoxical situation, Martin's work of translating "Wheaton's Elements of International Law" and published it as Wanguo Gongfa in Chinese was much important as its impact prevailed in late imperial China under Quing dynasty as a greater tool to ascertain European power politics. Especially this translation was regarded by the ministerial office of the Quing dynasty called Zongli Yamen as a useful sourcebook in its dealing with the European power in a decaying era of their heyday of Chinese superiority as the "Middle Kingdom" [18]. It seems to indicate this period and Martin's attempt of revealing western international law to China under the Quing dynasty beyond his mission of revealing gospels reached greater results as China began using European methods of international law in some instances. The events that took place after Prussia and Austria declared war against Denmark over the Schleswig-Holstein Question, Prussian envoy in China used a German warship to capture a Danish 
Amarasinghe, B.P.A, (2020)

Seeking the civilizational ghosts: Some remarks on Chinese and Russian approaches to international law through civilizational values

commercial vessel moored in the port of Dargu, Zongli Yaman saw it as a violation of international law as they learned from Martin's translation Wanguo Gongfa and used certain sections from the text to show their protest to Prussian envoy and Prussian envoy affirmed the mistake and released Danish commercial ship with a compensation. This incident illuminates the way China brilliantly grasped the western way of international within a shorter time period. In fact, Marin himself was satisfied with his work and how it influenced the Chinese. He stated:

"The Chinese people to whom I handed the translation of Wheaton's book immediately realized the benefits that could be drawn of it. They understood that if they make a mistake, they could use such knowledge of laws and regulations to blame it on other countries' oppressive means. It was also easy for me to see what the Chinese did not understand. What they did not understand was that when they file a suit on Europe's compliance with international law, both parties must mutually assume suitable obligations. This is a high-level concept that is used in the practical stage, and not when they have just started learning international law" [19].

The indoctrination of international law in China in post opium war context rendered its understanding of the modern temporal world, yet, the ambivalence towards Western-centric international legal order remained unchanged in traditional Chinese legal consciousness. Embracing western international law and its diplomatic practice further pushed China to understand the urgent necessity of forming "standards of civilization". One notable example can be traced to a letter written by the British minister in China in the late Quing dynasty Sir Rutherford Alcock. Alcock wrote this letter to Prince Gong in the Quing dynasty by urging the change of Confucian approach to state machinery. He states:

"Among the most revered of the ancient writings, there is one axiom which is not without application now. For Confucius taught, that 'when a system is exhausted it must be modified, that modified it will work, and that working it will endure.' The present machinery of the Chinese Administration is exhausted, and no longer fit for the work to be done. It requires modification to adapt it to a totally new order of wants" [20].

Nevertheless, it was clear that the Chinese did not have the genuine flare to accept European standards in politics and law as a central part of their state apparatus. Japan being the neighbor of China was ahead of the curve in terms of embracing Western political-ideological and technological strength under the Meji reforms of the late $19^{\text {th }}$ century. But in China regardless of Martens tireless efforts to enlighten Chinese by European international, disdainful nature towards foreigners remained unchanged. On the other hand, we need to understand that the Chinese attitude towards the West was based on prejudices, which always illuminated later was inferior to Chinese supremacy. The adoption of Western political mechanisms and

12 Journal of Legal Studies Volume 25 Issue 39/2020 $\checkmark$ sciendo ISSN 2457-9017; Online ISSN 2392-7054. Web: publicatii.uvvg.ro/index.php/jls. Pages $1-30$ 
Seeking the civilizational ghosts: Some remarks on Chinese and Russian approaches to international law through civilizational values

international law was not solely accepted by Chinese elites as they held a skeptic view towards Western nations solidly. In order to understand the persistent doubt Chinese elites maintained towards newly introduced international law, one should not forget the Chinese mental inferiority stuck by their subjugation before Western powers. Jacques de Lisles states:

"As Chinese scholars and officials learned about the newly encountered barbarian's international law. They expressed outrage at foreign states' use of ostensibly neutral or universal legal doctrines to advance self-interested agendas and the great powers. actions against China's sovereignty and territorial integrity" [21].

Secondly, in the course of understanding international legal norms, China understood Martin's depiction of international law based on natural law is not anymore applicable in the real world as the $19^{\text {th }}$-century interstate relations were mainly engulfed by the positivist dominance of Europe. The dualistic attitude of European nations towards international law in the $19^{\text {th }}$-century and the evasive manners they adopted in forming treaties with non-European nations were finally unveiled. Chinese realized that international law portrayed by Western scholars, missionaries like Martin was not the reality as they witnessed how their sovereignty was snatched by European powers without upholding the accepted norms in international law, I argue the moment China realized how unfairly they were trapped by the norms of Western international law, their belief in its legitimacy was marred. Also, in the minds of officials in Quing imperial court and other elites, international law was only perceived as a mere necessity to be on par with the European standard of the civilized state as Europe considered China a semi-civilized state. Yet, the Chinese were much adamant about their superiority than European powers. As the Chinese official named Li Hongzhang wrote in 1879:

"When China signed treaties with Britain and France before it was under the threat of force. We were threatened and deceived, treaties cause loses and they are outside the scope of international law" [22].

$\mathrm{Xu}$ Fucheng was another diplomat served as China's envoy to Britain and several other European countries. He also realized the duplicity of European international law and his observation during his stay in Europe affirmed that international law after Westphalia had caused harmony in European geopolitical order as it helped small states to coexist among great powers. Yet, he emphasized the applicability of international law in China was mainly focused on protecting European interests. Having observed how equally international law was applied in interstate affairs in Europe, $\mathrm{Xu}$ wrote in his diary:

"Once upon a time Westerners used international law to criticize us. The political elites at the time replied; China does not want to enter relations with you based on international law. Chinese and Western customs are different; how can you force us 
Amarasinghe, B.P.A, (2020)

Seeking the civilizational ghosts: Some remarks on Chinese and Russian approaches to international law through civilizational values

to be the same? We really do not care about international law. Since then the westerners have said that China is beyond the pale of international law and we have not been able to enjoy the benefits of international law...If we were strong ...nobody would accuse us if we oppose international law and refused to deal with Westerners. But since we are weak, if we had adhered to international law, at least we would have suffered as badly (as we have). What harm the past officials' careless remarks have caused us?" [23].

This was the pure reflection of Chinese towards international law and its reception in the late $19^{\text {th }}$ century and the imposed norms of international law by European powers in China were eventually terminated when China entered a different epoch with a different ideology after founding the People's Republic of China, where Chinese Communist Party simply discarded international law as a bourgeois product.

\section{The direction of international law after the formation of the People's Republic of China}

The disbandment of Chinese imperial order and the permanent end of traditional Chinese social order through the Communist upheaval raised a new question of seeking a new legal identity as it wiped out the Confucian influences that prevailed in pre-revolutionary China. The entire revolutionary discourse in China was not akin to the Bolshevik idea of revolution in Russia though China was heavily influenced by Marxist -Leninist thoughts. Nevertheless, the revolutionary efforts in China were predominantly mixed with Chinese nationalism that persisted even after the establishment of the People's Republic of China. Especially, since the death of Stalin, China began to diverge from Soviet ideological hegemony in pursuit of its unique place in the world that was motivated by the chairman's Mao's political ideology.

China's ambition of locating herself in her destined unique position in the world became the paramount feature of Chinese attitude towards international law since 1949. As I stated above, Chinese nationalism appeared to be the overarching principle of this broad project and by all means, it could be aptly understood why nationalism became a greater concern for Chinese vision of international law through tracing its colonial encounters with West and its decay of power at the hands of European nations. The treacherous usage of international law by European powers in favor of their power expansion such as forcing imperial China to enter into unequal treaties paved the path to create suspicion among Chinese elites towards international law. For them still, China held the helm in the civilized world and European international law was nothing more than an oppressive tool. The skepticism on universalized international law continued to exist in postrevolutionary China and the Communist party's astute mechanism of placing China in its unique place was very much aligned with its nationalism. Secondly, these bitter 
experiences China learned from its past encounters with Western nations enabled China to believe in its physical strength rather than believe in an international legal order. In fact, it was not just an expression when chairman Mao stated: "power grows out of the barrel of a gun ". He meant among other things that China had to face the reality that political and legal authority presupposes international physical power. In an article written by an American attorney named Daniel J. Hoffheimer titled "China and the International Legal Order; An Historical Introduction ", he states:

"pragmatism is the most important theme that parameters China 's ever-changing practice of international law. It possesses a dialectical capacity to turn adversity to advantage and weakness to strength. Despite the continuities in the past and China's bitter distrust of Western international legal rules and ideals, China has, in some important ways, become a zealous believer in some of the basic assumptions of the Western legal order [24]".

However, the changes primarily occurred in Chinese legal academia in postrevolutionary China has treated international law as a unique system which should not make any conflict with domestic law. As an example, Wang Tang China's premier jurist in the post-revolutionary era advocated for the mutual harmony and conspicuous separation of international law from domestic law. The academic discourse intensively grew in China caused some profound changes in their attitude toward international law and most of the Chinese scholars were enthusiastic in bringing Confucian philosophy to narrate modern international legal disputes. In particular, the reluctance of the Chinese government to approach the International Court of Justice as a method of settling international disputes could be perhaps understood as an issue arises from China's civilizational attitude towards $L i$. In its Confucian culture the prevalence of $L i$ always encouraged the disputants to solve their problems through mutual dialog rather than seeking justice from litigation, because in Confucian philosophy, the minimum order was characterized by the absence of litigation.

Chinese pragmatism on international legal order took a massive shift in 1978 when the Chinese government decided to open China to the world and to shift the work priority from class struggle to economic development. The rapid changes that took place in China for the past few decades transformed it into a modernized economic boomer that affected its systematic adoption of international law as a realist project. Chinese scholars primarily accepted and affirmed the priority of states in this paradigm shift of their attitude towards international law. Especially, Wang Tang was one of the key proponents who made a crucial empathy upon states. He states: "The sum total of principles, rules, regulations and systems which are binding and which mainly regulate interstate relations. while states are subject to the binding force of international law, they are also the makers of international law. Therefore, 
Amarasinghe, B.P.A, (2020)

Seeking the civilizational ghosts: Some remarks on Chinese and Russian approaches to international law through civilizational values

the basis for the legal effect of international law can only be attributed to states themselves, that is, the will of states" [25].

The bottom line of any inquiry exploring the civilizational features of Chinese attitude towards international law would be based on understanding China's political changes in transforming herself from a decadent imperial feudal state to a revolutionary state. Also, it requires to understand how the Chinese have assimilated Confucian order interpret international law and relations as their civilizational legacy. It is true that certain changes like pragmatism and flexibility entered Chinese perception about international law, yet the core element of Chinese legal thought $\mathrm{Li}$ still plays a paramount role in shaping China's global vision of international law as an influential factor of Chinese value system. Regarding the civilizational legacy predominantly appearing to be important in China, Prof. Pan Juwu states:

"In the Chinese mind, international law and international Li are generally inseparable and before the establishment of international Li, international law cannot be called a real law. In that case, priority should be given to the work of establishing or revisiting Li at the international level" [26].

\section{Modernity of Peter the Great and Russia's entry into international law}

The Russian position on international law prior to Peter the Great's herculean task of modernizing Russia remained much obscure. But, this twilight position does not affirm Russia was totally alienated from understating international legal practices during its initial stage as a community of principalities consisted of Rus tribe in the $10^{\text {th }}$-century. Russian nobility was known to medieval Europe and their rlations were extended to Germany, Poland and considered Byzantium to be their spiritual shrine. Nevertheless, Russian geopolitical space became completely obsolete and deviated from Western Europe when eKiev Russ principalities were crushed by Mongol invaders. Even, after Moscow Grand Duchy upheld its power over Mongol Tartars, the consequences of isolation from Latinized Western Europe continued to be visible in the Russian state apparatus. In ascertaining the intrinsic civilizational position of Russia on international law, one has to obviously look at its medieval dark political anarchism filled with catastrophic events. The influence of Russia's alienation from Western European states made the biggest impact of its entire history. From an international legal point of view, its effects were visible in $18^{\text {th }}$-century Russian diplomacy, even after Russia embraced Western modernity under Peter the Great.

Peter's victory over the Swedish empire in the Battle of Poltava was an iconic moment in Russian history in many ways. Politically, it proved Russia's position as a newly awakened giant from a long slumber as Peter's victory was followed by Russian entry into the Baltic region resulting in the Swedish decline. But, Peter's victory over Swedes became more decisive in Russian ideological history as the

16 Journal of Legal Studies Volume 25 Issue 39/2020

$\checkmark$ sciendo ISSN 2457-9017; Online ISSN 2392-7054.

Web: publicatii.uvvg.ro/index.php/jls. Pages $1-30$ 
Seeking the civilizational ghosts: Some remarks on Chinese and Russian approaches to international law through civilizational values

reforms implemented by Peter the Great in the aftermath of Poltava created a new space for Russia in the Western geopolitical map. A prominent scholar in Western academia on Russian approach to international law William E Butler states:

"Peter the Great's reign sharply accelerated what theretofore had been a gradual reception of European ideas. His keen interest in tapping Russia's natural resources, securing its frontiers, strengthening its military power, and reforming its antiquated institutions meant that western technology and learning were sought actively rather than tolerated passively. Agents were dispatched abroad to purchase libraries and recruit personnel. Facilitated by the introduction of a new civil script in 1708, the translation of European books into the Russian language increased, and young Russians were sent to study in European centers of learning" [27].

As Peter accelerated the modernizing process of Russia as a European state, the attitude towards international legal practice became more coherent from its old twilight form and under Peter's instruction European international law literature written by scholars like Grotius and Pundufft were translated into the Russian language. However, the attempt to assimilate Russia into Christian European nations who practiced international law was attributed to Peter Shafirov who served as a minister in the Court of Peter the Great.

Shafirov and his role in creating international law scholarship in Russia in a systematic way have been viewed from a different perspective in modern academia. The view expressed by Buttler towards Peter Shafirov has painted Shafirov as a less significant jurist who cannot be compared with the $17^{\text {th }}$ century canonical jurists in international law like Grotius, because Buttler viewed Shafirov's effort as a mere panegyric attempt to glorify Peter the Great and his victory over Swedes. But, I argue Shafirov's attempt of introducing international law to Tsarist Russia was more than an act of a panegyrist or rewriting the existing international legal practice. Because he explicitly showed his claim of Russia as a civilized country that can be on par with Western European states even though Russia stumbled upon ius publicum europaeum as a late comer. By the time Peter started his modernizing process in Russia, international law in Europe was relatively in a stable and advanced position. Especially, the reception of international law in Western Europe was considered a privilege and it was never regarded as a universalized law applicable to all the nations equally. The notion of "Civility" was the main yardstick that opened the gate for international law and civilized status was only confined to Latinized Europe, whereas the Ottomans, Africans and other nations outside Europe were excluded from this prestigious club.

The situation with Russia was rather peculiar and indeed, its legacy with Western Europe did not allow Russia to be completely isolated from Christian Europe, yet its domination under Mongol yoke for a longer period and the great schism with Rome 
Amarasinghe, B.P.A, (2020)

Seeking the civilizational ghosts: Some remarks on Chinese and Russian approaches to international law through civilizational values

made Russia's position incompatible with Western European nations. Also, the rift between Moscow and Latin Europe was not completely attributed to Western arrogance: rather, it was mutual [28]. In such a historical context, the attempt of Shafirov in his scholarly work was akin to an act of yielding to gain acceptance in the European club of international law. But, the trajectory developed in Pre Peterite Russia had disdained Latinized Europe as a heretic civilization that dwelled in the wrong faith. On the other hand, Constantinople, being the paragon held by Moscow as Second Rome fell into the hands of Ottomans in 1453, moreover, its union with Latinized Florence before its decline had already displeased Russians. Orthodox monk Filofei's letter to Moscow grand prince Vassilij III and Ivan the Terrible in the $16^{\text {th }}$ century had appealed both of Tsars to accept Moscow as Third Rome. The "Third Rome doctrine" developed by Filofei in the $16^{\text {th }}$ century seemed to have emboldened Russian Tsars to consider Russia's position the rightful place for Christianity and their attitude towards Latin nations took a skeptic approach [29]. In the backdrop of such a grim historical background, Peter Shafirov made his contribution of vitalizing international law in conformity with Western European standards. It is quite interesting how Shafirov was lamenting about the fact that Western ambivalence towards Russia and he struggled to prove Russia as a civilized, normal, European country. In writing his magisterial work, that happened to be the first Russian text on international legal practice, Shafirov stated:

"For several decades the Russian people and state have been discussed and written about in the other European States as are the Indians and the Persians and other peoples which have no communication with Europe except some trade. Russia was not seen as a participant in European matters of peace and war and was even rarely counted among the European nations" [30].

This paragraph indicates Shafirov`s infatuation with the system of civilized nations and notion of sovereign equality emerged after Westphalian order and more importantly his text denotes how ardently he determined to place Russia in the elite club of "law of nations "which was exclusively limited to the set of civilized nations in Europe. However, the irony of Shafirov's greatest desire to admit Russia to this elite club was not compatible with what Russian state interests stood for. In fact, this anomaly was one key feature that portrayed the conspicuous civilizational difference from Europeans. For instance, sovereign equality was one of the enshrined principles of the law of nations that Shafirov reverently adored. Yet, it was not a mere principle that arose out the blue as the acceptance of civilized Christian nations in Europe was rooted in the legacy of the Thirty Years War, which affirmed the system of ius publicum europaeum. But, this was not the system that Russia had adhered to practice. Filofei's "Third Rome" doctrine had imbued with Russian consciousness that urged Tsars and citizens to see Russia as a universalist state rather than another 
Seeking the civilizational ghosts: Some remarks on Chinese and Russian approaches to international law through civilizational values

equal sovereign with Latinized Europe. Peter the Great and his reforms could largely sweep off the archaic state apparatus in Russia, but it could not completely obliterate Russian cultural and ideological differences from Latin Europe regardless of how fervently Peter persuaded to Europeanize Russia. In such a context the attempt made by Peter Shafirov to depict Russia as a normal civilized state that could be on par with Latin states in Europe was an act against odds. Although he portrayed Russia as a state accustomed to international law, obliging to preserve sovereign equality, Peter the Great himself still regarded Russia as an imperial power. Shafirov being a panegyric to Peter legitimized Russian victory over Swedes and the legality of the disputed territory as a province under Russia's domination from ancient time. The conclusion of Shafirov's "Discourse "was written by Peter himself, where Tsar made some remarks completely contrary to Shafirov's idealistic vision of locating Russia in the family of international law. In conclusion, Peter states:

"By the assistance of Almighty God, Russia has now become formidable that we now see a nation who was the terror of almost of all Europe, vanquished by Russians. And I dare say, thanks to God alone. They dread no power whatsoever so much as Russia."

Peter Shafirov's work has left a significance in ascertaining Russia's civilizational value and the salient way it remained distinguished itself from European understanding of international law. From one hand it was an effort of a Russian jurist to justify the eligibility of his country to be a part of international law practised by Latinized Europe, but from the other hand, his self-claim on Russia's modernization as a normal Western state maintaining the required standards on preserving sovereign equality principle was refuted by Shafiriov's arguments that affirmed the omnipotence of Russian imperial policy, in particular, the views he shared in "The Discourse" about previous treaties Russia concluded with Sweden were completely written from his disdainful perspective towards Sweden and dismissed the validity of them as he viewed them as unjust to Moscow. In fact, his position of dismaying the previous treaties with Sweden was another notable factor which discloses civilizational legacy Russia revered, because the yardstick to determine a treaty in Russia had been completely a different practice from the West. In Latin Europe, the concept of a contract was based on reciprocity and the international legal maxim "Pacta sunt servenda" had its genesis from European practice. At the same time, the place of a treaty in Russia had a traditional approach which regarded entering into a contract as merely a humane matter. The disrespect for contracts as humane matters continued till the modernization of Peter, but even after Peter unveiled international law and European style statehood to Russia, it's old medieval attitude towards treaties and interstate relations remained prevalent. 
Amarasinghe, B.P.A, (2020)

Seeking the civilizational ghosts: Some remarks on Chinese and Russian approaches to international law through civilizational values

\section{Twisted Identity}

After the publication of Discourse by Shafirov, the next turning point of the Russian approach to international law appeared in the second half of the $19^{\text {th }}$ century with the works of Fyodor Fyodorovich Martens. As Lauri Malksoo aptly described "Martens" ideas were strongly influenced by who he was: a man from the border" [31]. Being an ethnic Estonian, his legal acumen was sharpened by the Germanic influence which was not strange at that time as the Baltic region and St. Petersburg were under the Germanic intellectual influence. In Martin's case, his obsession with westernizing Russia's international law discourse was a project that he persisted with the solid faith that international law would play a role as a "gentle civilizer of Russia "from its archaic roots. Indeed, Martin portrayed himself as a strong proponent of the idea of international law as an elite tool that applies only to civilized nations. But, his position cannot be merely regarded as a racist tendency. It was rather based on the sincere conviction of Martin regarding the liberality of Western attitude to international law as a more coherent and organized system that may grant more rights to its subjects. In his vision old Russia before Peter I was seen as an uncivilized country, his approach to revitalizing international law under Europeanization was sort of a civilizing project. He argued:

"It would be erroneous to consider Muscovy as a member of international exchange and to maintain that the Russian people and its government already at that time understood the necessity of international communication with Western powers. The foreign relations of Russia of that time were factual: in terms of its cultural conditions, social and political structure. Muscovy could not possibly have entertained steady legal relationships on the basis of equality and reciprocity. Such relations started only in the time of Tsar Peter the Great and only in the time of Catherine II received a firm basis [32]".

Nevertheless, Martin's effort was not adequate to liberate Russia from its aged old "otherness" and its different notion of international law. The real titillating position about Russia's identity had always imbued with its discontent with Western Europe and Russian understanding of the world has derived its legitimacy through Byzantium. It is not an exaggeration that tracing Russia's historical ties with Byzantium church illuminates understating her approach to international law. Martin's student Barron Michael Taube disrupted Martin's school and its ardor on Europeanizing the international law academia in Russia. Being Prof. Martin's own student, he further looked into the historiography of international law in Russia and argued the paramount role of Byzantium ideology in Russian history as an epochmaking factor. As an example, Taube has taken how bellum justum doctrine developed in the West in parallel to the separation of powers of the Pope and King which further indicated waging a war against another Christian state was essentially 
Seeking the civilizational ghosts: Some remarks on Chinese and Russian approaches to international law through civilizational values

evil. But this was not the doctrine professed by Byzantium relating war and its notion on war was determined by the will of the ruler [33]. In Taube's account, this civilizational difference between Latin Europe and Byzantium played a crucial position in filtering international law and diplomacy to Russia. Historically Russia was a confederation of an alliance of many independent principalities before the rise of Muscovy grand duchy in the $15^{\text {th }}$ century. Taube regarded those principalities such as Kiev, Vladimir and Moscow upheld their own medieval system akin to regional international law. Taube ignored Martin's argument of describing Russia as an uncivilized country prior to Peter the Great's reforms and his narrative on Russian history shows Russia continued its own standards in interstate relations and international law despite its antagonism with the West. However, Russia's relations with the West essentially began to wane by Mongol-Tarter invasion. He pointed out the main cause that rendered the separation of Russia from Republica Christiana as the two hundred years' domination of Mongol-Tarter rule in Russia and this rule left a despotic legacy in the Russian state system even after Mongol-Tartar rule was defeated in 1481. Taube states:

"The old confederation of Russian principalities and republics with more or less internationalist tendencies were absorbed in a new Empire with Moscow as a political center, in a unitary and despotic state, oriental in the foundation and halfway Tartar, halfway Byzantium, with orthodox mysticism and arrogant and aggressive nationalism. It is evident that these political changes in the political stricture of Eastern Europe did not remain without influence in the domain of international law and results could only be negative [34]".

The Tarter legacy transformed into a military state with an apish vison personality dwelled in a vision to lead Russia as a true Christian guardian. In fact, a letter written by a papal delegate to Moscow during the rule of Ivan IV had stated: "These people think that the whole world is subordinated to their sovereign and that all people are but his slaves ".

Perhaps, Taube's view can create a certain uproar for international law theorists today as his views on the scope of international law apotheosized its European superiority and he lamented Russia lost its greater opportunity to be a part of Republica Christiana as a result of Tartar domination which resulted in exposing Russia to oriental despotism and Asiatic practices. At a lecture at Kiel University in 1927, Taube stated:

"There were two Russia's. The pro-European upper class and the enormous halfAsiatic Slavic-Finnish-Tatar mass of the people that was unfortunately also very barbarian [35]".

Byzantium upbringing upon Russia's national consciousness as a paramount factor continued albeit Russia's exposition to Western Europe. The authority of Tsar as a 
Amarasinghe, B.P.A, (2020)

Seeking the civilizational ghosts: Some remarks on Chinese and Russian approaches to international law through civilizational values

divine representative on earth and Russia's persistent claim for the authenticity of its Christian heritage further deviated its affinity with Europe. The reforms carried out by Peter the Great and his successors in modernizing Russia in accordance with Western European traditions could not completely abandon Russia's Byzantium heritage and in examining its role in international law that one needs to understand Russian imperial policy at that time was much eager to preserve its otherness from Latin Europe. It's part of European concert in Vienna in 1815, its cultural fascination towards France such as a speaking French like a language of elegance or its intellectual debt to Germany in academia played less significant roles pushing Russia exclusively towards Western international law.

The civilizational difference of considering themselves unique was not entirely diminished when Russia was engulfed by a massive chain of events in the early $20^{\text {th }}$ century which finally produced the world's first socialist state USSR based on Communist ideology. International legal scholarship existed prior to the 1917 revolution was strongly affected by the Bolshevik regime as Marxian ideology inherently loathed law as an oppressive tool. Lenin's own position depicted in State and Revolution was similarly applicable towards international law as well in a disdainful way, but gradually the Soviet Union began to realize the inevitability of dealing with international law despite their ideological abhorrence on it [36]. In particular, the international legal scholarship bloomed after 1917 negated themselves from considering the universality of international law in accordance with any international legal thought, instead, their concern on state sovereignty as a cardinal argument took an adamant approach. Even though the state was rejected by Marxian doctrine, the Soviet jurists secured state centrism as they opposed to individualcentrism. The greatest dilemma loomed before Soviet jurists were to locate international law following Communist ideology, in doing so they placed international law's validity under the guise of Soviet state interests. Prominent early generation Soviet jurist Yevgeni Korovin initially argued that the Soviet Union should create their own discourse on international law and denied the universality principle, but later he modified his coarse criticism on international law by replacing it with a phase called "International law in a time of transition" [37]. Having consolidated such a pretext, the Soviet Union continued to promote the concept of socialist international law as an intrinsic form of international law applicable between the USSR and other socialist states. On the other hand, it is important to note that the Soviet attitude to international law throughout the Cold War era was based on the foreign policy of Moscow. The intensity of changes took place in Kremlin always made its impacts upon the changes in Soviet interpretation of international law. Maliksoo has aptly given a vivid picture of the susceptibility of Soviet international law doctrine under their changing political principles. He states: 
Seeking the civilizational ghosts: Some remarks on Chinese and Russian approaches to international law through civilizational values

"To the extent that Soviet foreign policy changed from Stalin to Khrushchev, for instance-international legal doctrine changed as well, and instead of the more hostile Korovin, the more conciliatory Tunkin became more prominent [38]".

All in all, the central tenants of the Soviet reception of international law were akin to their political principles, yet, the traditional aged long Muscovy's routine of sate centrism remained static as a Tsarist ghost from Imperial Russia and it was rather paradoxical as Soviets painted state as the devil incarnate.

\section{Civilizational thinking in Post-Soviet international law}

Many anticipated with some sanguine hopes Russia would return to Europe after the collapse of their communist empire and this hope was fueled by a sense of optimism shown by Boris Yeltsin when Russia officially joined the European Court of Human Rights in 1998. Many pundits described it as an act symbolizing Russia's yearn to embrace European values as she did under Peter the Great in the $18^{\text {th }}$ century. Nevertheless, the Russian position of international law in Post-Soviet space did not entirely transform into a lenient one. Especially, the crisis erupted after the annexation of Crimea and the constant reports on human rights abuses have raised a big question mark before international legal practice in contemporary Russia. It seems to indicate that Russia's historical uniqueness of being away from Latin Europe still shapes its legal thinking. For instance, Russia's denial of admitting individuals as a subject of international law stands as a pivotal feature in post-Soviet confrontation with western international law. The abundant attention upon state sovereignty over any other rights has not been forsaken in the post-Soviet era and perhaps in examining Russia's role in the aftermath of the Crimean crisis that one can regard Russia has fervently deviated from European liberal values. President Putin's remarks at Federal Assembly in 2002 on upholding its state supremacy can be regarded as Russia's state policy on maintaining their vastness as it was preserved under Tsars and Communists unchanged. Putin stated:

"All our historical experience testifies: such a country as Russia many live and develop in the existing borders only if it is a powerful state. Maintenance of the state in a vast space, preservation of the unique community of the people while keeping strong positions of the country in the world that is not only enormous work [39]".

Given the statement of the Russian leader denotes why Russia eagerly strives for protecting territorial sovereignty while keeping low enthusiasm over issues such as individual rights, human rights and non-state actors. The civilizational difference between Russia and the West has become double-edged sword as Russia's real civilizational position in international law appears ambiguous. In fact, we cannot entirely exclude Russia from European civilization and its intellectual influences. This twisted dilemma has perhaps sharpened Russia as a unique civilization and the 
Amarasinghe, B.P.A, (2020)

Seeking the civilizational ghosts: Some remarks on Chinese and Russian approaches to international law through civilizational values

sui generis practice Russia upholds in international law can be regarded as an offshoot of this civilizational uniqueness. The argument I illustrated above regarding the reluctance of Russia throughout its history in denying to accept individuals as subjects of international law shows the country's dogmatic views inevitably clashing with Western values and ironically this position has undergone some fewer changes in the annals of history since Tsarist regime to present Russian federation. During the period of the Soviet Union that any effort to uplift individual rights or admitting individuals as subjects of international law got nipped in the bud with vehement opposition of Soviet jurists. Soviet opposition pointed out bringing individuals as a subject of international law would lead to undermine state sovereignty and propagate western liberal values. However, the staunch state centrism prevails in Russian international law scholarship even after the fall of communism convinces the continuity of Soviet tradition as an inherent part of modern Russian international law. A distinguished Russian Jurist Prof Yuri M Kolovos once affirmed that removal of Marxist-Leninist ideology has not completely changed the main features of Russian international legal theory and it remained essentially the same as it was in the USSR with a strong emphasis on state sovereignty and legal positivism [40].

In seeking the civilizational roots of the Russian approach to international law, we need to further investigate the puzzling debate remains unanswered about Russia's destined position in civilizational order. Contemporary Russia keeps one foot in European space and its institutional legacies reminding of Peter's Europeanization, but simultaneously it keeps other foot in its own unique civilization as a critique of European liberal values. The old aged antagonism between Orthodox Russia and Latin Europe seems to have resurrected from a different way as Russia still adheres to its Muscovy tradition of orthodoxy while Europe reciprocates it with a sense of skepticism. It is a fact and not even a conjuncture that the notion of civilization has solidly made some strong impacts on Russia's attitude to international law. The argument developed by Russian scholar Safronova proves the crucial importance of civilizational difference in ascertaining some of the features Russia determines to uphold in its approach to international law. She states:

"Values that have primary importance in Europe and American civilization, are less important to other people. Thus, many Western ideas such as individualism, liberalism, democracy and separation of church and state and so on are not reflected in Orthodox, Muslim, Buddhist and Confucian cultures. The nature of the categories of freedom, justice and equality is understood differently. Different civilizations, for example, do not reject human rights or human freedom but understand and evaluate it differently. Unfortunately, current legal standardization takes place based on West European legal culture [41]". 
Seeking the civilizational ghosts: Some remarks on Chinese and Russian approaches to international law through civilizational values

\section{Conclusions}

As I stated at the beginning of this paper, the evaluating process of civilizational values and its contributions to international law is a horrendous task that brings detrimental results. Yet, the above mentioned unique two civilizations China and Russia have proven the utter importance of their own civilizational values in embracing international law. The Confucian model and its deeper influence upon Chinese history set the cause of transform Chinse psyche into a mind of a recluse who shared nothing except the contempt for other civilizational values. The Chinese notion of the middle kingdom and their lack of understanding of equal treaties never sprang out of the blue as those principles were completely excluded from Chinese civilizational thinking. Also, the intrinsic political and cultural legacy in Russia has galvanized its own system of international law with a little bit of an exposition to European intellectual influences. The civilizational distance of Russia from Europe has always shown Russia's own heritage in many spheres and I attempted to illustrate the anomaly born out of Muscovy tradition and its constant clash with Latin Europe. This confrontation has stood throughout history regardless of Russia's internal changes and it still stands form today.

Nevertheless, the fact we need to understand is that concept of "civilization" in international law should not be taken with veneration as how European colonizers relied upon in the $19^{\text {th }}$ century by creating a distinction between Europe and the rest of the world. Mainly, the general scope of modern international law deals with states and not with different civilizations. But, analyzing the civilizational values in particular countries widen the gaze to appreciate and understand their stances properly regarding some of the key issues in international law. In this paper in assessing the historical approaches maintained by China and Russia towards international law, I described how both states showed a cynical tendency in certain features in international law which were deeply admired by the West. In tracing their lethargic position over those issues such as principle sovereign equality and admitting the individual rights, I aptly described the solid influence laid down by both Chinese and Russian civilizational values over their legal acumen. The given example of Russian Orthodox ideology nourished by Byzantium heritage of admitting the authority of ruler's supremacy and its deep influence upon state centrism of Russian attitude to international law further proves connectivity between civilizational values and international law in modern Russia.

The saga of modern international law has been deeply rooted in modern European history and its contributions. The desire of Europeans to seeks common unity of their civilizational values in the political-legal sphere was escalated after the defeat of Napoleon and their ardent motivation to uplift social, political and cultural values 
Amarasinghe, B.P.A, (2020)

Seeking the civilizational ghosts: Some remarks on Chinese and Russian approaches to international law through civilizational values

common to all European nations became the fundamental inspiration for the great creation of international law. Author Guizot states:

"Civilization is a sort of ocean, constituting the wealth of the people, and on whose bosom all the elements of the life of that people, all the powers supporting its existence, assemble and unite. It is evident that there is a European civilization; that a certain unity pervades the civilization of the various European states [42]“.

The civilizational values Europeans adored became arch pillars of their standards of international law and their claim over its legitimacy was frequently boasted by this civilizational rhetoric. The $19^{\text {th }}$-century European international law scholars could not imagine universalizing international law beyond European geopolitical space as their concept of international law was a unique product of the special civilization of modern Europe. This created the dilemma of extending international law to the nations outside Europe as Europeans hesitated whether they were privileged to be a part of this elite club. Some Victorian commentators believed that states that did not fall under European civility will be admitted to international law gradually, in particular when a state is brought by increasing civilization within the realm of law. Their civilizational superiority often excluded Non-European states from entering into the shrine of international law. Even the Ottoman Empire and its legal practice were seen by European scholars as semi-civilized mechanism despite European states had been making treaties with Ottoman sultans since the $16^{\text {th }}$ century. The humiliation envisaged by Chinese at European hands in accepting unequal treaties was more or less a part of this civilizational haughtiness.

Nevertheless, the two historical approaches of two unique countries on international law that I analyzed in this paper have clearly shown the notion of civilizational arrogance was not only aggrandizement confined to Europe. On the contrary Chinese pride of their position as the middle kingdom or only civilization in the world and Russia's ambivalence of accepting Latin Europe and its values with its Orthodox dogma show us the importance of the civilizational role in carving international law. A plethora of historical, religious and philosophical roots pervaded in both Chinese and Russian societies played a vast role in emboldening them to consider themselves unique. It becomes rather conspicuous those roots played a dominant role in emboldening their modern-day practices such as a strict sense of state centrism.

The duty that appears before modern international law historians or scholars is not to persist the retrospection of the civilizational rhetoric as the $19^{\text {th }}$ century European scholars did. But understating the regional difference based on civilizational legacies in different places is vitally important fact to fathom how international law functions. the entire saga of international law may stand as a quest to seek the universality and unity for all the states. but it will never get rid of the civilizational differences that have painted different colors in the history of international law.

26 Journal of Legal Studies Volume 25 Issue 39/2020

$\checkmark$ sciendo ISSN 2457-9017; Online ISSN 2392-7054.

Web: publicatii.uvvg.ro/index.php/jls. Pages $1-30$ 
Seeking the civilizational ghosts: Some remarks on Chinese and Russian approaches to international law through civilizational values

\section{Acknowledgments}

The author thanks the anonymous reviewers and editor for their valuable contribution.

\section{Funding}

This research received no specific grant from any funding agency in the public, commercial, or not - for - profit sectors.

\section{Author Contributions}

The entire article was written by Battagodage Punsara Aravinda Amarasinghe.

\section{Disclosure Statement}

The author has not any competing financial, professional, or personal interests from other parties.

\section{References}

1. Amarasinghe, P., (2019). Re-Assessing the Depth of State and International Law in Soviet Ideology, Studi Europene, No.14.

2. Amarasinghe, P., Jayawardane, E., (2018). Is Sri Lanka Going to be the next China town in the Indian Ocean? Countercurrents.

3. Butler, W.E., (2002). On the Origins of International Legal Sciences in Russia: The Role of P.P. Shafirov, Journal of History of International Law, 4.J, 1.

4. Chi-Hua Tang, C.H., (2012). China-Europe, The Oxford Handbook of the History of International Law, Edited: Bardo Fassbender \& Anne Peters, Oxford University Press.

5. deLisle, J., (2000). China's Approach to International Law: A Historical Perspective, Proceedings of the Annual Meeting (American Society of International Law), Vol.94.

6. Elleman, B.A., (2019). The Making of the Modern Chinese Navy: Special Historical Characteristics, Anthem Press.

7. Guizot, F., (1997). The History of Civilization in Europe, London: Penguin.

8. Hall, W.E., (1880). A Treatise on International Law.

9. Hoffheimer, D.J., (1979). China and the International Legal Order: An Historical Introduction, Case Western Reserve Journal of International Law, Vol 11, 2.

10. Junwu, P., (2011). Chinese Philosophy and International Law, Asian Journal of International Law, 1.

11. Kennedy, D., (1996). International Law and the 19th Century: History of an Illusion, Nordic Journal of International Law.

12. Kennedy, D., (1999). The Discipline of International Law and Policy, Leiden Journal of International Law, Vol 12, Number 1.

13. Klimenko, A., Yurtaev, V., (2019). "The Moscow as the Third Rome" concept: Its nature and interpretations since the 19th to early 21 st centuries", Geopolitica Revista de estudios sobre espacio y poder, vol 9, no 2. 
Amarasinghe, B.P.A, (2020)

Seeking the civilizational ghosts: Some remarks on Chinese and Russian approaches to international law through civilizational values

14. Malksoo, L., (2008). The History of International Legal Theory in Russia: a Civilizational Dialog With Europe, The European Journal of International Law, Vol.19, no.1.

15. Malksoo, L., (2016). International Legal Theory in Russia: A Civilizational Perspective or can individuals be subjects of international law, The Oxford Handbook of the Theory of International Law (Edited by: Anne Orford, Florian Hoffmann and Martin Clark).

16. Malksoo, L., (2017). Russian Approach to International Law, Oxford University Press.

17. Meerills, J.G., (1968). Francisco de Vittoria and the Spanish conquest of the new world, Irish Jurist, Vol.3, No.1.

18. Orakhelashvili, A., The Idea of European International Law, The European Journal of International Law, Vol 17,2, 45.

19. Ruiz Fabri, H., Jouannet, E., Tomkiewicz, V. (Eds.), (2008). Select Proceedings of the European Society of International Law.

20. Ruskola, T., (2016). China in the Age of the World Picture, The Oxford Handbook of the Theory of International Law, Edited by Anne Oxford \& Florian Hoffman.

21. Safronova, E.V., (2013). Mezhdunarodnoe publichnoe pravo, Teoreticheskie problemy, (RIOR Moscow).

22. Shafirov, P., (1973). A Discourse Concerning the Just Causes of the War between Sweden and Russia: 1700-1721, (Introduction by W.E. Butler).

23. Snyder, E.A., Bracht, H.W., (1958). Coexistence and International Law, The International and Comparative Law Quarterly, Vol.7, No.1.

24. Suzuki, D.S., Civilization and Empire: China and Japan's Encounter with European International Society, New International Relations.

25. Tin-bor Hui, V., (2008). 'How China Was Ruled', The American Interest, Vol. 3, No. 4. 26. Turner, K., (1993). War, Punishment, and the Law of Nature in Early Chinese Concepts of the State, Harvard Journal of Asiatic Studies, Vol.53, No. 2.

27. Wang, T., Wei, M. (eds), (1981). International Law, Law Press Beijing.

28. Ward, R., (2011). An Enquiry into the Foundation and History of the Law of Nations from the Times of Greeks and the Romans to the Age of Grotius, revised edition.

29. Yin, Z., (2017). Heavenly Principles? The Translations of International Law in 19th century China and the Constitution of Universality, European Journal of International Law, Vol. 4 no. 4.

\section{Notes}

[1] J.G Meerills, Francisco de Vittoria and the Spanish conquest of the new world, Irish Jurist, Vol.3, No.1, 1968, p.189.

[2] David Kennedy, The Discipline of International Law and Policy, Leiden Journal of International Law, Vol 12, Number 1,1999, p.17.

[3] Pan Junwu, Chinese Philosophy and International Law, Asian Journal of International Law, 1, 2011, p.234.

[4] Ibid.

[5] Teemu Ruskola, China in the Age of the World Picture, The Oxford Handbook of the Theory of International Law, Edited by Anne Oxford \& Florian Hoffman, 2016, p.145. 
Amarasinghe, B.P.A, (2020)

"Vasile Goldiş" Western University of Arad

Seeking the civilizational ghosts: Some remarks on Chinese and Russian approaches to international law through civilizational values

[6] Zhiguang Yin, Heavenly Principles? The Translations of International Law in 19th century China and the Constitution of Universality, European Journal of International Law, Vol 4 no 4, 2017. P.1012.

[7] Victoria Tin-bor Hui, 'How China Was Ruled', The American Interest, Vol. 3, No. 4 (2008), p. 58.

[8] Bruce A. Elleman, The Making of the Modern Chinese Navy: Special Historical Characteristics, Anthem Press, 2019, p.23.

[9] Karen Turner, War, Punishment, and the Law of Nature in Early Chinese Concepts of the State, Harvard Journal of Asiatic Studies, Vol.53, No. 2, 1993, p.287.

[10] Punsara Amarasinghe, Eshan Jayawardane, Is Sri Lanka Going to be the next China town in the Indian Ocean? Countercurrents, 2018.04.08.

[11] Pan Junwu, Chinese Philosophy and International Law, Asian Journal of International Law, 1, 2011, p.234.

[12] Chi-Hua Tang, China-Europe, The Oxford Handbook of the History of International Law, Edited: Bardo Fassbender \& Anne Peters, Oxford University Press, 2012, p. 704.

[13] Zhiguang Yin, Heavenly Principles? The Translations of International Law in 19th century China and the Constitution of Universality, European Journal of International Law, Vol 4 no 4, 2017. P.1012.

[14] William Edward Hall, A Treatise on International Law, 1880, p.39.

[15] David Kennedy, International Law and the 19th Century: History of an Illusion, Nordic Journal of International Law, 1996, 6.

[16] Robert Ward, An Enquiry into the Foundation and History of the Law of Nations from the Times of Greeks and the Romans to the Age of Grotius, revised edition, 2011, p.271.

[17] Alexander Orakhelashvili, The Idea of European International Law, The European Journal of International Law, Vol 17,2, 45.

[18] Chi-Hua Tang, China-Europe, The Oxford Handbook of the History of International Law, Edited: Bardo Fassbender \& Anne Peters, Oxford University Press, 2012, p. 460.

[19] Ibid., p.467.

[20] Di Shogo Suzuki, Civilization and Empire: China and Japan's Encounter with European International Society, New International Relations, p.92.

[21] Jacques deLisle, China's Approach to International Law: A Historical Perspective, Proceedings of the Annual Meeting (American Society of International Law),2000, Vol.94, p.67.

[22] Chi-Hua Tang, China-Europe, The Oxford Handbook of the History of International Law, Edited: Bardo Fassbender \& Anne Peters, Oxford University Press, 2012, p. 460.

[23] Di Shogo Suzuki, Civilization and Empire: China and Japan's Encounter with European International Society, New International Relations, p.74.

[24] Daniel J. Hoffheimer, China and the International Legal Order: An Historical Introduction, Case Western Reserve Journal of International Law, Vol 11, 2, 1979, p.264.

[25] T. Wang and M. Wei, (eds), International Law, Law Press Beijing, 1981, p.1.

[26] Pan Junwu, Chinese Philosophy and International Law, Asian Journal of International Law, 1, 2011, p.238. 
Amarasinghe, B.P.A, (2020)

Seeking the civilizational ghosts: Some remarks on Chinese and Russian approaches to international law through civilizational values

[27] William E. Butler, On the Origins of International Legal Sciences in Russia: The Role of P.P. Shafirov, Journal of History of International Law, 4.J, 1, 2002, p.6.

[28] Lauri Malksoo, The History of International Legal Theory in Russia: a Civilizational Dialog With Europe, The European Journal of International Law, Vol.19, no.1, 2008, p.216. [29] Anna Klimenko, Vladimir Yurtaev, "The Moscow as the Third Rome" concept: Its nature and interpretations since the 19th to early 21st centuries", Geopolitica Revista de estudios sobre espacio y poder, vol 9, no 2, 2019, p.235.

[30] P. Shafirov, A Discourse Concerning the Just Causes of the War between Sweden and Russia: 1700-1721, (Introduction by W.E. Butler),1973, p. 2.

[31] Lauri Malksoo, The History of International Legal Theory in Russia: a Civilizational Dialog With Europe, The European Journal of International Law, Vol.19, no.1, 2008, p.221. [32] Ibid.

[33] Lauri Malksoo, Russian Approach to International Law, Oxford University Press, 2017, p.123.

[34] Ibid.,

[35] Ibid., p.126.

[36] Punsara Amarasinghe, Re-Assessing the Depth of State and International Law in Soviet Ideology, Studi Europene, No.14, 2019, p.73.

[37] Earl A. Snyder, Hans Werner Bracht, Coexistence and International Law, The International and Comparative Law Quarterly, Vol.7, No.1, 1958, p.62.

[38] Lauri Malksoo, International Legal Theory in Russia: A Civilizational Perspective or can individuals be subjects of international law, The Oxford Handbook of the Theory of International Law (Edited by: Anne Orford, Florian Hoffmann and Martin Clark), 2016, p.260.

[39] Ibid., p.271.

[40] H. Ruiz Fabri, E Jouannet and V Tomkiewicz (eds), Select Proceedings of the European Society of International Law,2008, p.169.

[41] EV Safronova, Mezhdunarodnoe publichnoe pravo, Teoreticheskie problemy, (RIOR Moscow), 2013, p.43.

[42] F. Guizot, The History of Civilization in Europe, London: Penguin, 1997, p.11. 